\title{
Reform of China's Environmental Governance: The Creation of a Ministry of Ecology and Environment
}

\author{
WANG Jinpeng \\ Lecturer, School of Law and Political Science \& Institute of Marine \\ Development, Ocean University of China, Qingdao \\ wangjinpeng@ouc.edu.cn
}

\section{Introduction}

This note focuses on the creation of the Ministry of Ecology and Environment (MEE), a milestone in China's environmental governance. Section 2 provides a background of the creation of the MEE. Section 3 documents the plan of institutional restructuring and other decisions relevant to the establishment of MEE. Section 4 explains how the MEE unifies responsibilities for environmental protection and facilitates coordination. The final section discusses future challenges and potential problems facing the MEE.

Over the last forty years, China's environmental regulatory agencies have carried out numerous reforms. With the inspiration of the Stockholm Conference on Human Environment, China established the first national environmental protection agency in 1974 'the State Council Leading Group Office of Environmental Protection.' ${ }^{\prime}$ Since then, as pollution problems became more prominent and environmental protection was increasingly valued, this body was gradually developed and reformed. In 2008, the cabinet-level Ministry of Environmental Protection (MEP) was established. It was in charge of formulating and implementing environmental protection plans, policies and standards.

* This work is supported by the Fundamental Research Funds for the Central Universities (grant number: 201813005) and the Qingdao Postdoctoral Applied Research Project.

1 In Chinese: “国务院环境保护领导小组.

(C) WANG JINPENG, 2018 | DOI:10.1163/24686042-12340026

This is an open access article distributed under the terms of the prevailing CC-BY-NC license at the time of publication. 
Although the status of the MEP was improved and strengthened over time, some relevant functions were decentralized to other agencies. For example, the MEP, the Ministry of Water Resources (MWR), the Ministry of Land and Resource (MLR) and the former Ministry of Health carried out water quality monitoring in their respective areas. The MEP was responsible for air pollution control, while the National Development and Reform Commission (NDRC) was dedicated to controlling greenhouse gases and combating climate change. The MEP was responsible for the control of land pollution, whilst the State Oceanic Administration (SOA) was in charge of preventing marine pollution, often from land sources. The term 'nine dragons rule the waters' (九龙治水) was used by state officials and scholars to describe the regulatory situation. ${ }^{2}$ Ultimately, bureaucratic fragmentation and overlapping of responsibilities led to a lack of coordination and ineffective regulation.

An institutional restructuring plan of the State Council of China was delivered at the fourth plenary meeting of the first session of the 13th National People's Congress (NPC) on 13 March $2018 .^{3}$ A very positive change in the reform is the establishment of the MEE of China. The purpose of establishing MEE is to integrate hitherto fragmented ecological environmental protection responsibilities and to unify supervision and enforcement responsibilities. ${ }^{4}$ The establishment of MEE reflects the fact that China is trying to unify fragmented responsibilities for environment governance into a single body and to practice the idea of ecosystem-based management in the institutional setup at the national level. One of the requirements of ecosystem-based management is that management efforts must recognize the complexities and vulnerabilities of

2 See eg SUN Yi and GAO Jing, 环保部部长李干杰: 组建生态环境部将实现 “五个打 通"' [LI Ganjie (Minister for Environmental Protection): The Establishment of the Ministry of Ecology and Environment Will Achieve 'Five Open Links'] (17 March 2018) <http://www .xinhuanet.com/politics/2018lh/2018-03/17/c_1122551701.htm> accessed 7 May 2018.

3 See XIN Dingding, 'China Announces Cabinet Reshuffle Plan to Streamline Government Work' China Daily (13 March 2018) <http://usa.chinadaily.com.cn/a/201803/13/ WS5aa7224ca3106e7dcc1412f6.html $>$ accessed 26 April 2018.

4 See WANG Yong (a State Councillor), ‘关于国务院机构改革方案的说明' [Explanation on the Institutional Reform Plan of the State Council] (14 March 2018) <http://www.gov.cn/ guowuyuan/2018-03/14/content_5273856.htm> accessed 27 April 2018. 
ecosystems. ${ }^{5}$ Therefore, it is preferable for various environmental elements to be managed under an integrated institutional framework.

China has emphasized the idea of ecosystem-based management several times in recent years. The explanatory notes for the Decision of the Central Committee of the Communist Party of China (CPC) on Some Major Issues Concerning Comprehensively Deepening the Reform, stated by President XI Jinping in 2013, underline that 'mountains, waters, forests, farmlands and lakes form a community of life,' and recognizes the need for a single department to 'carry out unified protection and restoration programs.' ${ }^{6}$ The Integrated Reform Plan for Promoting Ecological Progress promulgated by the CPC Central Committee and the State Council in 2015 highlights that ecological progress could be achieved with approaches of environmental protection and restoration that are based on a comprehensive and systemic approach. The plan promotes two important directions: first, the assignment to a single department of all responsibilities related to environmental protection; second, progressively creating a system whereby one department is responsible for unified regulation and administrative law enforcement. ${ }^{7}$ Promoted by the Decision and the Plan, the idea of ecosystem-based management drove the institutional restructuring, and the MEE was finally established in early 2018.

\section{$4 \quad$ The Unification of the Decentralized Responsibilities}

To unify responsibility for environmental protection and facilitate coordination, the institutional restructuring plan integrates relevant responsibilities currently spread throughout different agencies into the new MEE. In addition to all the responsibilities previously held by the MEP, the MEE replaces:

- The NDRC concerning climate change mitigation,

- The MLR concerning the control of underground water pollution,

5 See Mark T IMPERIAL, 'Institutional Analysis and Ecosystem-Based Management: The Institutional Analysis and Development Framework' (1999) 24(4) Environmental Management 449, 451.

6 XI Jinping, "Explanatory Notes for the "Decision of the Central Committee of the Communist Party of China on Some Major Issues Concerning Comprehensively Deepening the Reform"' (29 January 2014) <http://en.people.cn/102774/8525250.html> accessed 27 April 2018.

7 See CPC Central Committee and State Council, “生态文明体制改革总体方案” [Integrated Reform Plan for Promoting Ecological Progress] (21 September 2015), English version available at <http://english.gov.cn/policies/latest_releases/2015/og/22/content_281475195492066 .htm> accessed 23 April 2018. 
- The MWR concerning water-function zoning, sewage outlet setting and watershed environmental protection,

- The Ministry of Agriculture concerning the control of agricultural nonpoint source pollution,

- The SOA concerning the protection of the marine environment, and

- The South-to-North Water Diversion Project Construction Committee concerning environmental protection during the implementation of this particular project. ${ }^{8}$

As the most powerful dedicated environmental regulatory body in the history of China, the MEE is responsible for compiling and implementing China's ecological environment policies, plans and standards as well as monitoring the environment. More specifically, the MEE is responsible for pollution control and ecological protection, including the soil and subsurface, the shore and the water, the land and the sea, the city and the countryside, carbon monoxide and carbon dioxide..$^{9}$ Moreover, the MEE regulates nuclear and radiation safety, and organizes inspections of central authorities on environmental protection.

The MEE also plays an important role in coordinating the enforcement of China's environmental laws. According to the Plan on Deepening Reform of Party and State Institutions promulgated by the СРC Central Committee, China shall establish a comprehensive law enforcement team, integrate law enforcement responsibilities and uniformly implement law enforcement for ecological and environmental protection. The MEE is authorized to guide and coordinate this reform. ${ }^{10}$ The integration and unification of law enforcement will help the MEE to implement environmental legislation and regulations with greater efficiency and consistency across China.

Whilst great progress has been made, inter-ministerial coordination will remain necessary. The most obvious area where coordination is needed concerns the relationship between the MEE and Ministry of Natural Resources (MNR). The MNR is responsible for the division and management of natural resources

8 See the Thirteenth National People’s Congress, ‘国务院机构改革方案’ [State Council Institutional Restructuring Program] (17 March 2018) <http://www.gov.cn/xinwen/2018 -03/17/content_5275116.htm > accessed 3 May 2018.

9 See SUN and GAO (n 2).

10 CPC Central Committee, “深化党和国家机构改革方案” [The Plan on Deepening Reform of Party and State Institutions] (21 March 2015) <http://www.gov.cn/zhengce/2018-03/21/ content_5276191.htm\#1> accessed 5 May 2018. 
such as land, forests, grasslands, wetlands and water resources. It also manages the newly-established National Forestry and Grassland Administration (NFGA) which manages nature reserves and national parks in China.. ${ }^{11}$ The coordination between the MEE and the MNR in some cases seems inevitable, for example in response to risks of water pollution affecting national parks. This coordination should seek to reconcile the intrinsic value of the environment protected by the MEE with the economic value of natural resources that the MNR seeks to develop.

The MEE must also work with the Ministry of Emergency Management to create coherent and effective policies regarding environmental emergency responses. And because energy efficiency and industrial upgrading plans are formulated by the NDRC, the MEE must still cooperate with it to address climate change. In a word, coordination and cooperation between the MEE and other departments remains a key characteristic of environmental governance in China.

The unification of responsibilities is also to be encouraged at local levels. It has frequently been pointed out that local governments regularly intervene to promote economic or industrial development at the cost of environmental protection. China has taken actions to establish a system of vertical management to ensure the implementation of environmental law by local authorities. In 2016, the Central Office of the CPC and the General Office of the State Council released Guidelines on the Pilot Program of Vertical Management Reform of Environmental Monitoring, Inspection and Law Enforcement below the Provincial Level. ${ }^{12}$ The Guidelines request that provincial environmental protection agencies implement unified supervision and administration of environmental protection in the provinces, and that local party committees and governments adopt a more responsible attitude towards environmental protection. The vertical management reform helps in insulating environmental protection agencies from inappropriate intervention by local governments. ${ }^{13}$ After the establishment of local environment and ecology departments, they must take up the tasks of enhancing the effectiveness of vertical management reform and further rationalizing their relationship with local governments.

\footnotetext{
11 See ibid.

12 Central Office of the CPC and General Office of the State Council, ‘关于省以下环保机 构监测监察执法垂直管理制度改革试点工作的指导意见' [Guidelines on the Pilot Program of Vertical Management Reform of Environmental Monitoring, Inspection and Law Enforcement below the Provincial Level] (September 2016) <http://www.xinhuanet .com/politics/2016-09/22/c_1119608354.htm> accessed 29 April 2018.

13 See MA Yun, 'Vertical Environmental Management: A Panacea to the Environmental Enforcement Gap in China?' 1 (2017) Chinese Journal of Environmental Law 37, 52.
} 


\section{$6 \quad$ Conclusion}

The situation of pollution control and ecological protection in China is serious. For instance, according to the 2016 Report on the State of the Environment, the air quality of $75.1 \%$ cities did not meet the standards in 2016 , several watercourses are seriously polluted, and China's marine ecosystems are significantly affected. ${ }^{14}$ The establishment of the MEE in 2018 favours integration of functions related to environmental protection. It can adopt a comprehensive and coherent approach to pollution control, wildlife protection and nuclear safety. With the establishment of the MEE, how precisely its unified functions are implemented will continue to be an important issue. Undoubtedly, the MEE is better equipped than the previous MEP to address the formidable environmental challenges that it faces.

14 MEP, '2016 Report on the State of the Environment in China' (September 2017) <http:// english.sepa.gov.cn/Resources/Reports/soe/> accessed 5 May 2018. 